Article

\title{
Effects of Arbuscular Mycorrhizal Fungi on Growth, Photosynthesis, and Nutrient Uptake of Zelkova serrata (Thunb.) Makino Seedlings under Salt Stress
}

\author{
Jinping Wang ${ }^{1}$, Zhiyuan Fu ${ }^{1}$, Qiong Ren ${ }^{2}$, Lingjun Zhu ${ }^{1}$, Jie Lin ${ }^{1}$, Jinchi Zhang ${ }^{1, *}$, \\ Xuefei Cheng ${ }^{1}$, Jieyi Ma ${ }^{1}$ and Jianmin Yue ${ }^{1}$ \\ 1 Co-Innovation Center for Sustainable Forestry in Southern China, Jiangsu Province Key Laboratory of Soil \\ and Water Conservation and Ecological Restoration, Nanjing Forestry University, 159 Longpan Road, \\ Nanjing 210037, China; wangjp0304@163.com (J.W.); fuzhiyuannjfu@outlook.com (Z.F.); \\ zlj940506@outlook.com (L.Z.); linjiecn@gmail.com (J.L.); CaroC1127@outlook.com (X.C.); \\ JYM9c307@outlook.com (J.M.); jianminyue@njfu.edu.cn (J.Y.) \\ 2 Wetland Centre, Jiangxi Academy of Forestry, Nanchang 330032, China; jane5872@126.com \\ * Correspondence: zhang8811@njfu.edu.cn; Tel.: +86-854-272-02
}

Received: 31 January 2019; Accepted: 15 February 2019; Published: 20 February 2019

check for updates

\begin{abstract}
Salinity is the primary restriction factor for vegetation conservation and the rehabilitation of coastal areas in Eastern China. Arbuscular mycorrhizal fungi (AMF) have been proved to have the ability to alleviate salt stress in plants. However, the role of AMF in relieving salt stress among indigenous trees species is less well known, limiting the application of AMF in the afforestation of local area. In this study, a salt-stress pot experiment was conducted to evaluate the effects of AMF on Zelkova serrata (Thunb.) Makino, a tree species with significant potential for afforestation of coastal area. The Z. serrata seedlings inoculated with three AMF strains (Funneliformis mosseae 1, Funneliformis mosseae 2, and Diversispora tortuosa) were subjected to two salt treatments ( 0 and $100 \mathrm{mM} \mathrm{NaCl}$ ) under greenhouse conditions. The results showed that the three AMF strains had positive effects, to a certain extent, on plant growth and photosynthesis under normal condition. However, only F. mosseae 1 and F. mosseae 2 alleviated the inhibition of growth, photosynthesis, and nutrient uptake of $Z$. serrata seedlings under salt stress. The two AMF strains mitigated salt-induced adverse effects on seedlings mainly by increasing the leaf photosynthetic ability and biomass accumulation by reducing $\mathrm{Na}^{+}$content, increasing $\mathrm{P}, \mathrm{K}^{+}$, and $\mathrm{Mg}^{2+}$ content, as well as by enhancing photosynthetic pigments content and the stomatal conductance of leaves. These results indicated that AMF inoculation is a promising strategy for the afforestation of coastal areas in Eastern China.
\end{abstract}

Keywords: arbuscular mycorrhizal fungi; salt stress; plant growth; photosynthesis; nutrients uptake

\section{Introduction}

Coastal areas represent unique ecosystems between ocean and land, and are globally distributed from the Arctic and Antarctic to Tropical zones [1]. They are valuable land reserve resources, drawing global attention for their vegetation conservation and rehabilitation [2]. The Jiangsu coastal area is 6520 million square meters, occupying more than one-quarter of the total coastal area in China. However, owing to complicated factors disturbing soil fertility, such as high salt accumulation, shallow water table, and frequent inclement weather, vegetation rehabilitation of local coastal area has not been effectively accomplished. The primary and serious limitation affecting vegetation conservation and 
rehabilitation in this area is salinity. Excess salt content in soil restricts water and nutrient absorption by plants, adversely affecting the ion balance in plants [3]. Moreover, high salt accumulation in plants above threshold levels could cause ion injury and oxidative damage to plants, leading to the disruption of cell membrane integrity, metabolic disorder, weakened activities of biocatalysts, and inhibition of the photosynthetic ability of leaves, ultimately resulting in restricted plant growth and development $[4,5]$.

The association of plant roots with arbuscular mycorrhizal fungi (AMF) is an important ecological strategy to help plants survive in saline environments [6]. AMF are a type of plant-growth-promoting microorganism that can form a mutualistic relationship with more than $80 \%$ of plant species in terrestrial ecosystems, including in saline environments [7,8]. Many researchers have reported that AMF may increase the salt tolerance of plants and improve the rhizosphere soil environment $[9,10]$. The mechanisms that AMF employ to enhance the salt tolerance of plants to grow and develop in saline environments include facilitating water and nutrient absorption through extraradicular hyphae [3,11], maintaining more favorable $\mathrm{K}^{+} / \mathrm{Na}^{+}$ratios to alleviate toxic ions effects [12], accumulating more proline and other organic solutes to reduce osmotic stress [13], increasing the synthesis and effectiveness of some enzymes to mitigate oxidative damage [3], inducing the expression of stress-related genes and proteins [14], and improving rhizosphere soil health [10]. However, knowledge of how AMF affect growth and the salt tolerance of indigenous trees species in coastal areas, especially in Eastern China, is limited.

Zelkova serrata (Thunb.) Makino is a temperate, broad-leaved deciduous tree species of the Ulmaceae widely distributed in the south of Yellow River, China. It belongs to two class key protected plants of China. As an important economic and landscape indigenous tree species in Jiangsu, China, $Z$. serrata timber is used for construction, especially for building temples, shrines, and high-quality furniture. Z. serrata is well-adapted to grow in local, mildly saline soil, and is a promising candidate for afforestation of coastal areas [15]. However, the seedlings of $Z$. serrata have low survival rates in the soil of local coastal areas owing to high soil salinity, which restricts their use for afforestation of this area. Hence, the present study was conducted based on the hypothesis that AMF could promote the growth and salt tolerance of $Z$. serrata seedlings. A pot experiment was performed in a greenhouse to determine the effect of three AMF strains (Funneliformis mosseae 1, Funneliformis mosseae 2, and Diversispora tortuosa) on the growth (seedlings height and base diameter growth, leaf area, and biomass of leaves, stems, and roots), photosynthesis (photosynthesis parameters, photosynthetic pigments, and chlorophyll fluorescence parameters), relative water content and membrane stability index of leaves, and nutrients contents $\left(\mathrm{C}, \mathrm{N}, \mathrm{P}, \mathrm{K}^{+}, \mathrm{Ca}^{2+}, \mathrm{Mg}^{2+}\right.$, and $\left.\mathrm{Na}^{+}\right)$in the leaves and roots of $Z$. serrata under salt stress $(100 \mathrm{mM} \mathrm{NaCl})$. The results obtained revealed the effects of AMF on growth, photosynthesis, and nutrient uptake of Z. serrata seedlings under salt stress, and could contribute to gaining a better understanding of AMF application in afforestation and vegetation rehabilitation in coastal areas.

\section{Material and Methods}

\subsection{Plant Seedlings, AMF Inocula, and Soil}

The seeds of Z. serrata were collected from healthy adult trees in Nanjing Forestry University, China, in October 2016. Before germination, the seeds were mixed with wet sand at 1:3 ratio and stored in a refrigerator at $4{ }^{\circ} \mathrm{C}$. After 30 days, the seeds were soaked in $3 \mathrm{~g} / \mathrm{L} \mathrm{KH}_{2} \mathrm{PO}_{4}$ solution for $24 \mathrm{~h}$, surface-sterilized with $75 \%$ ethanol solution for $5 \mathrm{~min}$, and washed with distilled water. Then, the seeds were allowed to germinate on culture dishes in a plant incubator under humid conditions. The germinated seeds were transferred to a seedling-raising disk and cultivated with peat soil. Prior to the transfer of germinated seeds, the peat soil was autoclaved at $0.14 \mathrm{MPa}$ and $121^{\circ} \mathrm{C}$ for $2 \mathrm{~h}$, and the seedlings were cultivated in phytotron under optimum conditions from March to May 2017.

F. mosseae 1, F. mosseae 2, and D. tortuosum were provided by the Institute of Plant Nutrition and Resources, Beijing Academy of Agriculture and Forestry Sciences, China. The three AMF strains were propagated using maize and clover as host plant. The culture substrate was yellow sand, which 
was autoclaved at $0.14 \mathrm{MPa}$ and $121{ }^{\circ} \mathrm{C}$ for $2 \mathrm{~h}$ before inoculation. After 3 months, a mixture of spores (density $>7 / \mathrm{g}$ ), including infected root fragments, mycorrhiza, and sand were harvested as AMF inocula.

The pot experiment was conducted in a greenhouse of Xiashu Forest Farm, Nanjing Forestry University. The topsoil $(5-30 \mathrm{~cm})$ from Xiashu Forest Farm was collected, and its physicochemical properties were determined as follows: total $\mathrm{N}, 0.03 \%$; total $\mathrm{P}, 570.48 \mathrm{mg} \mathrm{kg} \mathrm{k}^{-1}$; available $\mathrm{P}$, $10.00 \mathrm{mg} \mathrm{kg}^{-1}$; total $\mathrm{K}, 15.18 \mathrm{~g} \mathrm{~kg}^{-1}$; available $\mathrm{K}, 101.39 \mathrm{mg} \mathrm{kg}^{-1}$; total $\mathrm{C}, 1.55 \%$; electrical conductivity $0.23 \mathrm{mS} \mathrm{cm}^{-1}$ (soil:water ratio, 1:5); and $\mathrm{pH}, 7.15$ (soil:water ratio, 1:5). Before the pot experiment, the soil was sieved through a $2-\mathrm{mm}$ sieve and mixed with yellow sand and vermiculite as nursery substrates (soil/sand/vermiculite, 1:1:1, v/v/v). The nursery substrates were autoclaved at $0.14 \mathrm{MPa}$ and $121^{\circ} \mathrm{C}$ for $2 \mathrm{~h}$, and left in the greenhouse for at least 2 weeks.

\subsection{Inoculation and Experimental Design}

Seedlings of uniform height (mean height $15 \mathrm{~cm}$ ) were selected for inoculation at the beginning of June 2017. Prior to the experiment, the pots (27-cm deep and $21-\mathrm{cm}$ diameter) were soaked in $0.3 \%$ $\mathrm{KMnO}_{4}$ solution for $3 \mathrm{~h}$ and washed with tap water. The experiment comprised four AMF groups: pots inoculated with F. mosseae $1\left(\mathrm{FM}_{1}\right)$, F. mosseae $2\left(\mathrm{FM}_{2}\right)$, D. tortuosum (DT), and autoclaved AMF inocula (control without AMF, NM), respectively, with each group consisting of 24 replicates, totaling to 96 pots. Each pot was filled with $2.5 \mathrm{~kg}$ of autoclaved nursery substrates and $80 \mathrm{~g}$ of inoculum. First, two-third of the autoclaved nursery substrates was added to the pot with the inoculum placed under the surface of nursery substrates. Then, the seedling was transplanted to the pot, and the pot was filled with the remaining one-third of the nursery substrates. The seedlings were cultured in greenhouse from June 2017 to June 2018 at a temperature of $18{ }^{\circ} \mathrm{C}-35^{\circ} \mathrm{C}$, relative humidity of $40-80 \%$, day photoperiod ranging from 10 to $14 \mathrm{~h}$, and a mid-day photosynthetic photon flux density (PPFD) of about $1000 \mu \mathrm{mol} \mathrm{m} \mathrm{m}^{-2} \mathrm{~s}^{-1}$. The seedlings were watered six times with modified Hoagland's nutrient solution containing only $25 \% \mathrm{P}$ concentration $(300 \mathrm{~mL}$ per pot every time) during this period, and optimum moisture conditions were maintained.

The seedlings were subjected to salt stress from the end of June 2018 to end of August 2018. In brief, the seedlings of the four AMF groups were divided into two categories and subjected to non-salt treatment (CK) and salt-stressed treatment (Salt), respectively. Once a week, the Salt seedlings were watered with an aqueous solution $(300 \mathrm{~mL}$ per pot) containing $100 \mathrm{mM} \mathrm{NaCl}$, whereas the CK seedlings were watered with normal water $(300 \mathrm{~mL}$ per pot). During this period, the seedlings also received $300 \mathrm{~mL}$ of modified Hoagland's nutrient solution containing only $25 \% \mathrm{P}$ per pot every month.

\subsection{Plant Growth Parameters and AMF Colonization}

The plant height and base diameter were measured before and after salt stress. The leaves, stems, and roots were weighed after drying them at $70 \mathrm{C}$ until a constant weight. The leaf area was measured using a LA2400 Scanner (Expression 12000XL, EPSON, Long Beach, CA, USA). The fine roots were cut into 1-cm-long segments, soaked in $10 \%(w / v) \mathrm{KOH}$, incubated in a water bath $\left(90{ }^{\circ} \mathrm{C}\right)$ for $1 \mathrm{~h}$, stained with basic $\mathrm{H}_{2} \mathrm{O}_{2}$ (containing $30 \mathrm{~mL}$ of $10 \%(v / v) \mathrm{H}_{2} \mathrm{O}_{2}, 3 \mathrm{~mL}$ of concentrated $\mathrm{NH}_{4} \mathrm{OH}$, and $60 \mathrm{~mL}$ of water) for $25 \mathrm{~min}$, soaked in $1 \%(w / v) \mathrm{HCl}$ for $3 \mathrm{~min}$, stained with $0.05 \%(\mathrm{w} / \mathrm{v})$ Trypan Blue solution, and placed in a water bath $\left(90^{\circ} \mathrm{C}\right)$ for $30 \mathrm{~min}$ [16]. Subsequently, the roots were soaked in lactic acid-glycerol (1:1) to eliminate excess Trypan Blue solution, and examined for the presence of AMF structures under a semi-automatic digital microscope (Leica DM5000B, Wetzlar, Germany) at 100-400× magnification. The percentage root colonization was calculated using the following equation:

$$
\text { root colonization }(\%)=\frac{\text { Number of arbuscular mycorrhiza }- \text { positive segments }}{\text { Total number of segments studied }} \times 100
$$




\subsection{Leaf Photosynthesis, Photosynthetic Pigments, and Chlorophyll a Fluorescence}

Photosynthesis parameters, including leaf net photosynthetic rate $\left(P_{\mathrm{n}}\right)$, stomatal conductance $\left(G_{\mathrm{s}}\right)$, and transpiration rate $\left(T_{\mathrm{r}}\right)$, were measured in the third expanded leaf during the day between 09:30 and 11:30 before harvest using a portable photosynthesis system (LI-6400, LI-COR, Lincoln, NE, USA). The parameters were determined under the following conditions: photosynthetically active radiation, $1000 \mu \mathrm{mol} \mathrm{m}{ }^{-2} \mathrm{~s}^{-1} ; \mathrm{CO}_{2}$ concentration, $390 \mu \mathrm{mol} \mathrm{mol}^{-1}$; leaf temperature, $25{ }^{\circ} \mathrm{C}$; leaf humidity, 35-50\%; and air flow rate, $0.5 \mathrm{dm}^{3} \mathrm{~min}^{-1}$. The water use efficiency (WUE) was calculated as the ratio of $P_{\mathrm{n}}$ and $T_{\mathrm{r}}$.

Subsequently, chlorophyll fluorescence was ascertained during the day between 09:30 and 11:30 using a portable fluorometer (MINI-PAM-II, WALZ, Effeltrich, Gemany). After the leaves were adapted to darkness for $30 \mathrm{~min}$, the minimal florescence $\left(F_{\mathrm{o}}\right)$ and maximum florescence $\left(F_{\mathrm{m}}\right)$ of the leaves were determined using a saturating pulse of about $5000 \mu \mathrm{mol} \mathrm{m}^{-2} \mathrm{~s}^{-1}$. Then, the leaves were adapted to $800 \mu \mathrm{mol} \mathrm{m}{ }^{-2} \mathrm{~s}^{-1}$ light, and steady state of florescence $\left(F^{\prime}\right)$, maximum florescence $\left(F_{\mathrm{m}}{ }^{\prime}\right)$, and actual quantum yield of PSII photochemistry $\left(\phi_{\mathrm{PSII}}\right)$ were recorded. The data obtained were used to calculate the maximum efficiency of PSII $\left(F_{\mathrm{v}} / F_{\mathrm{m}}\right)$ and quantum yield of non-photochemical quenching (NPQ) [17]. Photosynthetic pigments, including chlorophyll a (Chl a), chlorophyll b (Chl b), and carotenoid (Car), were extracted using $0.2 \mathrm{~g}$ of fresh leaves in $25 \mathrm{~mL}$ of $80 \%$ acetone, and the absorbance of the extracts was determined at 663,645 , and $470 \mathrm{~nm}$, respectively [18].

\subsection{Leaf Water Status and Membrane Stability Index}

The relative water content in the leaves was measured according to the previously method [19] using the following formula: RWC $=$ (fresh weight - dry weight $) /$ (turgor weight - dry weight. The membrane stability index was estimated using the formula [20], MSI $=1-\mathrm{C} 1 / \mathrm{C} 2$, where $\mathrm{C} 1$ is the electrical conductivity bridge after the leaves were heated at $40{ }^{\circ} \mathrm{C}$ for $30 \mathrm{~min}$ in a water bath, and $\mathrm{C} 2$ is the electrical conductivity bridge after the leaves were boiled at $100^{\circ} \mathrm{C}$ for $10 \mathrm{~min}$ in a water bath.

\subsection{Leaf and Root Nutrients Content}

The leaves and roots of three plants from each treatment were harvested and dried in an oven at $70{ }^{\circ} \mathrm{C}$ until a constant weight. Then, the dried leaves and roots were ground separately and sieved through a $0.5-\mathrm{mm}$ sieve. Subsequently, $50 \mathrm{mg}$ of each sample were employed for the measurement of $\mathrm{C}$ and $\mathrm{N}$ concentrations using an elemental analyzer (Vario MACRO cube, Elementar Trading Shanghai, Shanghai, China). For the determination of the concentrations of other nutrients, including $\mathrm{P}, \mathrm{K}^{+}$, $\mathrm{Ca}^{2+}, \mathrm{Mg}^{2+}$, and $\mathrm{Na}^{+}, 0.2 \mathrm{~g}$ of each sample was digested in $10 \mathrm{~mL}$ of acid mixture $\left(\mathrm{HClO}_{4}: \mathrm{HNO}_{3}\right.$, 1:5) and diluted with double-distilled water to $100 \mathrm{~mL}$. The concentration of $\mathrm{P}$ was determined spectrophotometrically using ammonium molybdate blue method, whereas the concentrations of $\mathrm{K}^{+}$, $\mathrm{Ca}^{2+}, \mathrm{Mg}^{2+}$, and $\mathrm{Na}^{+}$were ascertained with an atomic absorption spectrophotometer (AA900T, Perkin Elmer, Norwalk, CA, USA) [21].

\subsection{Statistical Analysis}

Two-way analysis of variance (ANOVA) was employed to compare the treatments effects, and the treatments means were evaluated by Duncan's multiple range test $(p<0.05)$. All data analyses were performed using SPSS19.0 (SPSS Inc., Chicago, IL, USA), and all the figures were constructed using Origin 8.5 (OriginLab, Northampton, MA, USA).

\section{Results}

\subsection{AMF Colonization}

While vesicles, arbuscules, and hyphae were observed in the AMF-inoculated Z. serrata roots, no mycorrhizal colonization was found in the roots of $\mathrm{NM}$ group (Figure $1 \mathrm{~A}$ ). $\mathrm{FM}_{1}$ and $\mathrm{FM}_{2}$ groups 
exhibited higher mycorrhizal colonization than DT group under CK and salt stress conditions (Figure 1B). Salt significantly reduced mycorrhizal colonization in $\mathrm{FM}_{1}$ and DT groups $(p<0.05)$.
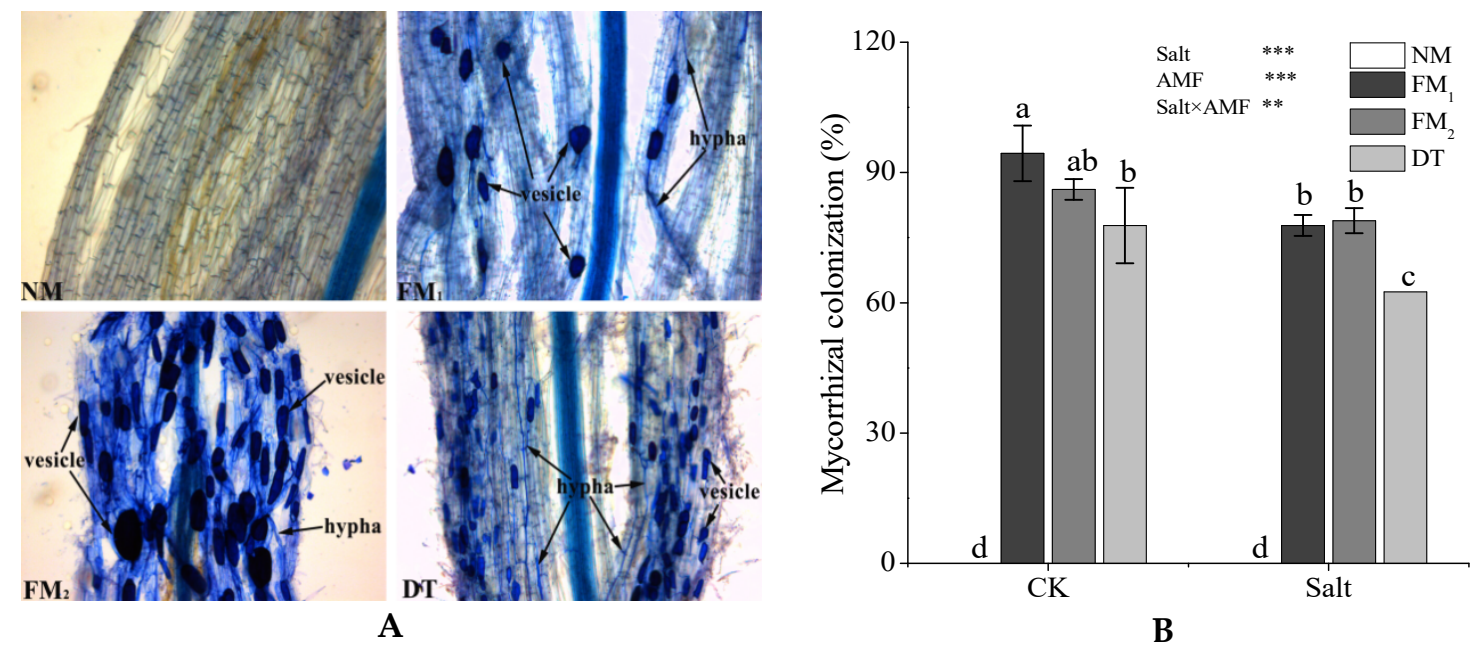

Figure 1. Development of the three arbuscular mycorrhizal fungi in Z. serrata seedling roots. (A) represents the figure of colonization status. (B) represents the figure of mycorrhizal colonization. CK represents the control without salt and AMF. NM represents the control treatments without AMF, $\mathrm{FM}_{1}$ represents treatments inoculated with the AMF Funneliformis mosseae 1, $\mathrm{FM}_{2}$ represents treatments inoculated with the AMF Funneliformis mosseae 2, DT represents treatments inoculated with the AMF Diversispora tortuosum. Different lowercase letters indicate significant differences between the three AMF under control and salt stress at the 0.05 significance level; NS not significant, ${ }^{*} p<0.05,{ }^{* *} p<0.01$, $* * * p<0.001$.

\subsection{Plant Growth}

Salt stress significantly decreased the growth of seedling height and diameter, leaf area, and leaf and stem dry weight $(p<0.05)$ (Table 1$)$. The increases in seedling height and diameter, as well as leaf area in the AMF-inoculated groups, were higher than those in the NM group under CK, but were not significant $(p>0.05)$. In contrast, under salt stress conditions, the growths of the seedling diameters increased by $50 \%(p<0.05), 55.55 \%(p<0.05)$, and $16.67 \%$ after inoculation with $\mathrm{FM}_{1}, \mathrm{FM}_{2}$, and DT, respectively. Nevertheless, only the $\mathrm{FM}_{1}$ group showed significant increase in the seedling leaf area $(p<0.05)$.

Furthermore, there was no difference in leaf, stem, and root dry weight and leaf area between the DT and NM groups under salt stress conditions, whereas the leaf dry weight increased by $30.95 \%$ and $16 \%$ after inoculation with $\mathrm{FM}_{1}$ and $\mathrm{FM}_{2}$. Additionally, the stem dry weight increased by $20.71 \%$ and $7.14 \%$ and the root dry weight increased by $22.53 \%$ and $15.49 \%$, respectively, for the $\mathrm{FM}_{1}$ and $\mathrm{FM}_{2}$ groups, respectively. However, no significant differences in plant growth and plant dry weight were observed between the $\mathrm{FM}_{1}$ and $\mathrm{FM}_{2}$ groups under $\mathrm{CK}$ and salt stress conditions. The effect of salt on all the indices was significant, whereas the effects of AMF and interaction of Salt and AMF (Salt $\times$ AMF) were not, except for the effect of AMF on leaf area. 
Table 1. Effects of three AMF strains on the growth of Z. serrata seedlings.

\begin{tabular}{|c|c|c|c|c|c|c|c|}
\hline Salt Status & $\begin{array}{c}\text { AM } \\
\text { Treatments }\end{array}$ & $\begin{array}{c}\text { Growth of Seedling } \\
\text { Height }(\mathrm{cm})\end{array}$ & $\begin{array}{l}\text { Growth of Seedling } \\
\text { Diameter }(\mathrm{cm})\end{array}$ & Leaf Area $\left(\mathrm{cm}^{2}\right)$ & $\begin{array}{l}\text { Leaf Dry Weight } \\
\text { (g) }\end{array}$ & $\begin{array}{l}\text { Stem Dry Weight } \\
\text { (g) }\end{array}$ & $\begin{array}{c}\text { Root Dry Weight } \\
\text { (g) }\end{array}$ \\
\hline \multirow[t]{4}{*}{ CK } & NM & $24.2 \pm 8.5 \mathrm{~b}$ & $3.0 \pm 1.7 \mathrm{ab}$ & $16.0 \pm 0.7 \mathrm{ab}$ & $7.5 \pm 0.9 \mathrm{ab}$ & $18.6 \pm 1.7 \mathrm{abc}$ & $9.9 \pm 1.9 \mathrm{ab}$ \\
\hline & $\mathrm{FM}_{1}$ & $29.2 \pm 7.1 \mathrm{ab}$ & $3.2 \pm 0.7 \mathrm{a}$ & $17.6 \pm 0.7 \mathrm{a}$ & $8.7 \pm 1.5 \mathrm{a}$ & $21.2 \pm 3.7 \mathrm{ab}$ & $10.6 \pm 2.2 \mathrm{ab}$ \\
\hline & $\mathrm{FM}_{2}$ & $35.5 \pm 5.4 \mathrm{a}$ & $2.9 \pm 0.5 \mathrm{ab}$ & $16.5 \pm 0.9 \mathrm{ab}$ & $8.0 \pm 0.3 \mathrm{a}$ & $19.7 \pm 3.2 \mathrm{abc}$ & $10.3 \pm 3.6 \mathrm{ab}$ \\
\hline & DT & $30.3 \pm 4.4 \mathrm{ab}$ & $3.1 \pm 0.7 \mathrm{a}$ & $16.4 \pm 2.0 \mathrm{ab}$ & $9.5 \pm 1.6 \mathrm{a}$ & $23.3 \pm 5.1 \mathrm{a}$ & $11.3 \pm 2.2 \mathrm{a}$ \\
\hline \multirow[t]{4}{*}{ Salt } & NM & $9.5 \pm 3.3 c$ & $1.8 \pm 0.4 \mathrm{c}$ & $10.9 \pm 1.1 \mathrm{c}$ & $4.2 \pm 1.0 \mathrm{c}$ & $14.0 \pm 1.4 \mathrm{~d}$ & $7.1 \pm 0.9 \mathrm{~b}$ \\
\hline & $\mathrm{FM}_{1}$ & $8.7 \pm 4.7 \mathrm{c}$ & $2.7 \pm 0.4 \mathrm{ab}$ & $14.3 \pm 0.6 b$ & $5.5 \pm 1.6 \mathrm{bc}$ & $16.9 \pm 1.0 \mathrm{bcd}$ & $8.7 \pm 0.2 \mathrm{ab}$ \\
\hline & $\mathrm{FM}_{2}$ & $9.6 \pm 5.4 \mathrm{c}$ & $2.8 \pm 0.6 \mathrm{ab}$ & $11.6 \pm 1.9 c$ & $5.0 \pm 1.3 \mathrm{c}$ & $15.0 \pm 1.5 \mathrm{~cd}$ & $8.2 \pm 0.5 \mathrm{ab}$ \\
\hline & $\mathrm{DT}$ & $8.9 \pm 4.5 c$ & $2.1 \pm 0.3 \mathrm{bc}$ & $10.2 \pm 0.7 \mathrm{c}$ & $4.2 \pm 0.2 \mathrm{c}$ & $14.2 \pm 0.9 \mathrm{~d}$ & $7.1 \pm 1.0 \mathrm{~b}$ \\
\hline \multicolumn{8}{|l|}{ Significance } \\
\hline Salt & & $* * *$ & $* *$ & $* * *$ & $* * *$ & $* * *$ & $* *$ \\
\hline AMF & & NS & NS & $* *$ & NS & NS & NS \\
\hline Salt $\times$ AMF & & NS & NS & NS & NS & NS & NS \\
\hline
\end{tabular}

Note: CK represents the control without salt and AMF. NM represents the control treatments without AMF, FM 1 represents treatments inoculated with the AMF Funneliformis mosseae 1 ,

$\mathrm{FM}_{2}$ represents treatments inoculated with the AMF Funneliformis mosseae 2, DT represents treatments inoculated with the AMF Diversispora tortuosum. Different lowercase letters indicate

significant differences between the three AMF under control and salt stress at the 0.05 significance level; NS not significant, ${ }^{*} p<0.05,{ }^{* *} p<0.01,{ }^{* * *} p<0.001$. 


\subsection{Leaf Photosynthesis, Photosynthetic Pigments, and Fluorescence Parameters}

The effects of salt stress and AMF on all the photosynthesis parameters were significant. Salt stress significantly decreased $P_{\mathrm{n}}\left(\mu \mathrm{mol} \mathrm{CO} \mathrm{Cm}^{-2} \mathrm{~s}^{-1}\right), G_{\mathrm{s}}\left(\mathrm{mmol} \mathrm{m}^{-2} \mathrm{~s}^{-1}\right)$, and $T_{\mathrm{r}},\left(\mathrm{mmol} \mathrm{H}_{2} \mathrm{O} \mathrm{m}^{-2} \mathrm{~s}^{-1}\right)$ $(p<0.05)$, but significantly increased WUE $(p<0.05)$ (Figure 2). A significant increase in $P_{\mathrm{n}}(p<0.05)$ after AMF inoculation under CK (Figure 2a) indicated that $\mathrm{AMF}$ enhanced the $\mathrm{CO}_{2}$ assimilation rate of Z. serrata seedlings. However, under salt stress conditions, only the $\mathrm{FM}_{1}$ and $\mathrm{FM}_{2}$ groups showed significant increase in $P_{\mathrm{n}}(p<0.05), \mathrm{G}_{\mathrm{s}}$, and $\operatorname{Tr}(p<0.05)$ (Figure $\left.2 \mathrm{~b}, \mathrm{c}\right)$. Moreover, under salt stress conditions, WUE of the NM group was significantly higher than that of the AMF groups $(p<0.05)$ (Figure 2d).
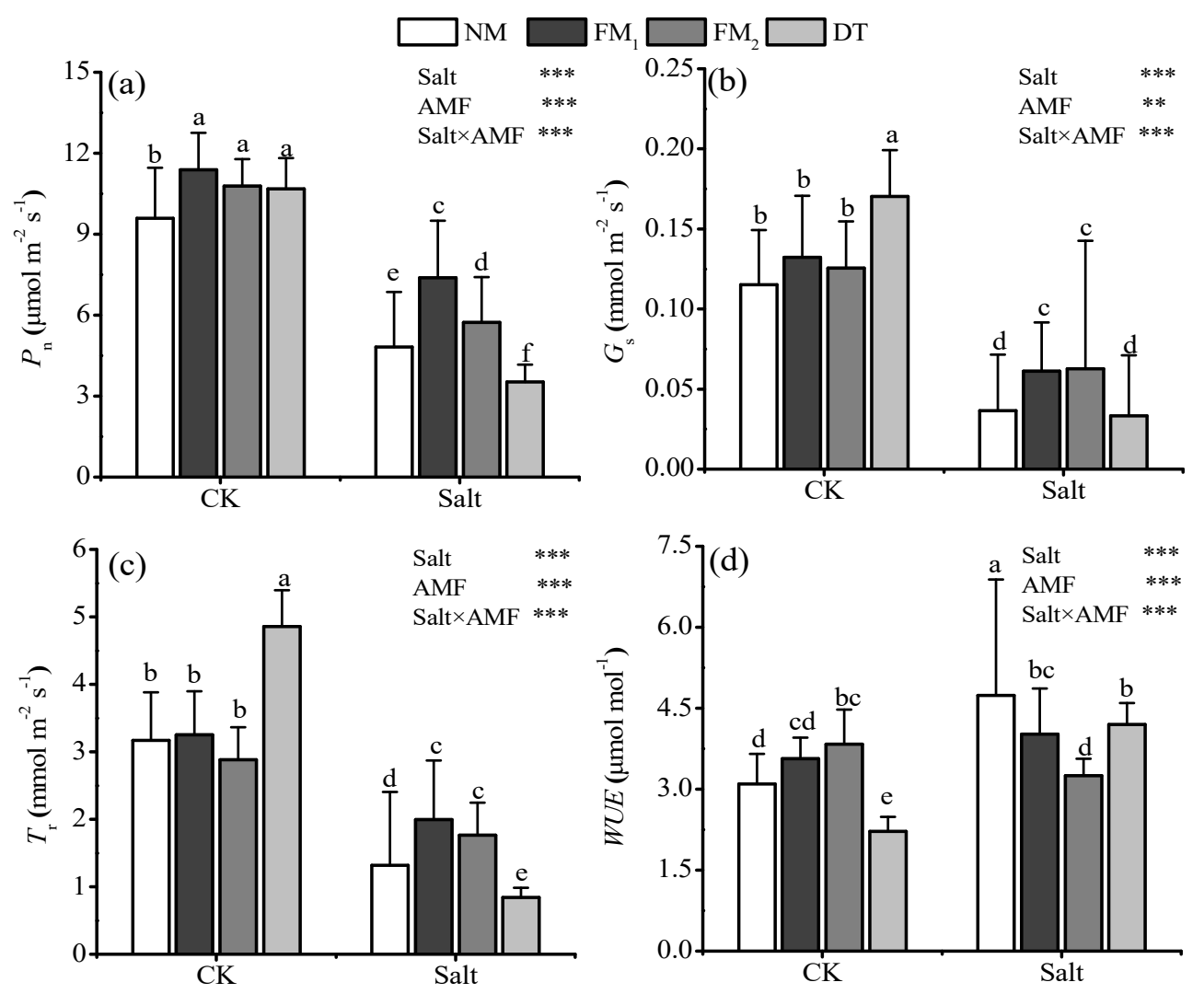

Figure 2. Effects of salt treatments and AMF inoculation on the plant net photosynthetic rate (a), stomatal conductance (b), transpiration rate (c), and water use efficiency (d) of Z. serrata seedlings leaves. Vertical bars indicate the standard error of the mean $(n=9)$. Different lowercase letters indicate significant differences between the three AMF under control and salt stress at the 0.05 significance level; NS not significant, ${ }^{* *} p<0.01,{ }^{* * *} p<0.001$.

While the effects of salt stress and AMF on photosynthetic pigments of Z. serrata seedlings leaves were significant (Figure 3A-C), the influences of the three AMF strains on the photosynthetic pigments varied. The DT group showed no changes in $\mathrm{Chl} \mathrm{a,} \mathrm{Chl} \mathrm{b,} \mathrm{and} \mathrm{Car} \mathrm{both} \mathrm{under} \mathrm{CK}$ and salt stress conditions. In contrast, the $\mathrm{FM}_{1}$ and $\mathrm{FM}_{2}$ groups presented $23.78 \%$ and $9.34 \%$ increase in $\mathrm{Chl}$ a, 32.02\% and $12.73 \%$ increase in $\mathrm{Chl} b$, and $21.37 \%$ and $8.46 \%$ increase in Car, respectively, under CK. Under the salt stress conditions, the $\mathrm{FM}_{1}$ group presented $27.20 \%, 33.07 \%$, and $17.21 \%$ increase in Chl a, Chl b, and Car, respectively, while the $\mathrm{FM}_{2}$ group showed $10.17 \%$ and $20.05 \%$ increase in $\mathrm{Chl}$ a and $\mathrm{Chl} b$, respectively (Figure $3 \mathrm{~A}, \mathrm{~B})$.

The Fv $/ F \mathrm{~m}, \phi_{\text {PSII }}$, and NPQ were significantly affected by salt stress, whereas only NPQ was significantly influenced by AMF (Figure 3D-F). Salt stress decreased $\phi_{\text {PSII }}$ by $41.86 \%(p<0.05)$ and increased NPQ by $100.42 \%(p<0.05)$. Among the three AMF groups, the DT group exhibited the 
most positive effect on $\phi_{\text {PSII }}$ under $\mathrm{CK}$, but presented the least positive effect on $\phi_{\text {PSII }}$ under salt stress conditions. The $\mathrm{FM}_{1}, \mathrm{FM}_{2}$, and DT groups demonstrated $31.38 \%, 17.90 \%$, and $2.66 \%$ increase in $\phi_{\mathrm{PSII}}$, respectively. In addition, the AMF groups exhibited higher mean NPQ, when compared with the NM group, and the increase was significant under CK. In particular, the DT group showed $32.42 \%$ increase in the value of NPQ.
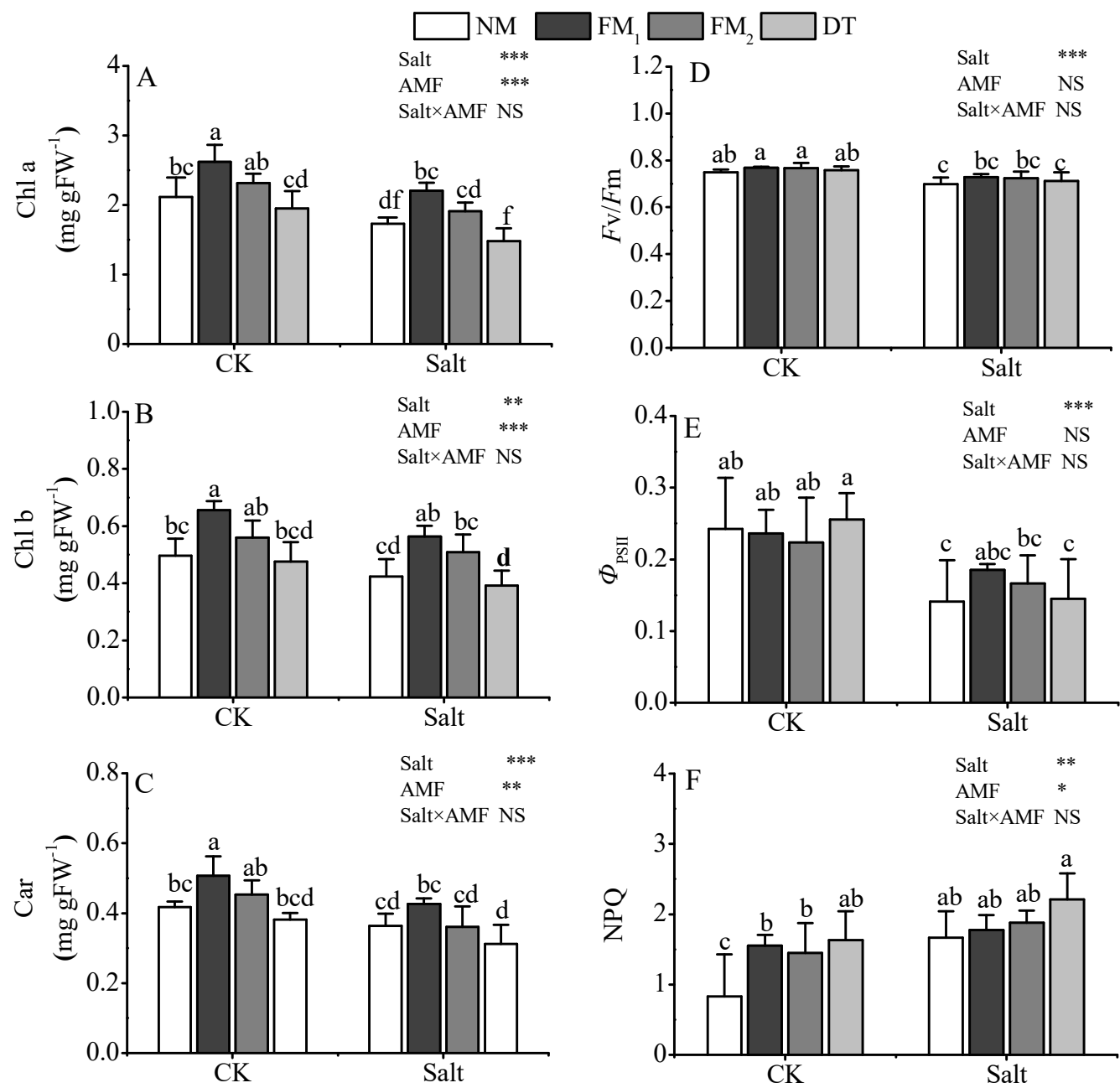

Figure 3. Effects of salt treatments and AMF inoculation on the photosynthetic pigments $(\mathrm{A}-\mathrm{C})$ and chlorophyll fluorescence (D-F) of Z. serrata seedlings leaves. Vertical bars indicate the standard error of the mean $(n=4)$. Different lowercase letters indicate significant differences between the three AMF under control and salt stress at the 0.05 significance level; NS not significant, ${ }^{*} p<0.05,{ }^{* *} p<0.01$, $* * * p<0.001$.

\subsection{Leaf Relative Water Content and Membrane Stability Index}

The leaf relative water content and membrane stability index were significantly affected by salt stress. The leaf relative water content in the AMF groups was higher than that in the NM group. Under $\mathrm{CK}$, the $\mathrm{FM}_{1}, \mathrm{FM}_{2}$, and DT groups presented $1.46 \%, 1.69 \%$, and 5.17\% increase in leaf relative water content after inoculation, respectively; however, under salt stress conditions, the values increased by $4.58 \%$ and $2.50 \%$ after inoculation with $\mathrm{FM}_{1}, \mathrm{FM}_{2}$, respectively, but decreased by $1.07 \%(p<0.05)$ after inoculation with DT. Membrane stability index of leaf in the $\mathrm{FM}_{1}, \mathrm{FM}_{2}$, and DT groups slightly increased after AMF inoculation, presenting 12.68\%, 13.11\%, and $11.24 \%$ increase under CK and 5.22\%, $1.61 \%$, and $2.53 \%$ increase under salt stress conditions, respectively (Figure 4 ). 


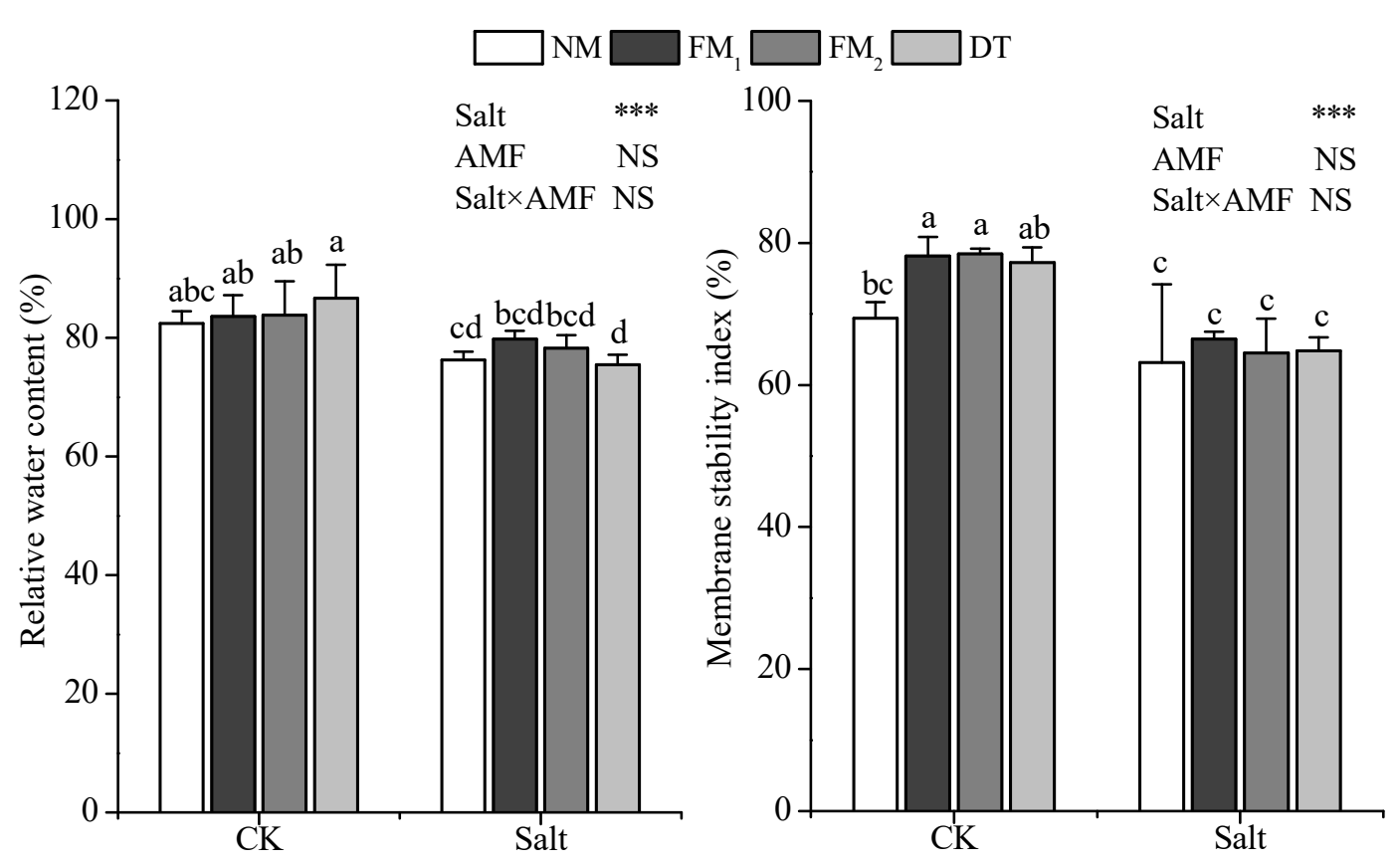

Figure 4. Effects of salt treatments and AMF inoculation on the relative water content and cell membrane stability index of $Z$. serrata seedlings leaves. Vertical bars indicate the standard error of the mean $(n=4)$. Different lowercase letters indicate significant differences between the three AMF under control and salt stress at the 0.05 significance level; NS not significant, ${ }^{* * *} p<0.001$.

\subsection{Leaf and Root Nutrients and Ions Contents}

The contents of $C, N$, and $P$ in the leaves and roots of $Z$. serrata seedlings were significantly affected by salt stress, whereas only the $P$ content in the roots of $Z$. serrata seedlings was significantly affected by AMF inoculation. Under salt stress conditions, the contents of $\mathrm{C}, \mathrm{N}$, and $\mathrm{P}$ in the leaves of $Z$. serrata seedlings decreased (Table 2), whereas the $\mathrm{N}$ content in the roots of $Z$. serrata seedlings increased. There was no significant difference in the $\mathrm{N}$ content in the leaves and roots of seedlings in the AMF groups and NM group. The P content in the leaves of $Z$. serrata seedlings increased by $18.82 \%$ and $10.59 \%$ after inoculation with $\mathrm{FM}_{1}$ and $\mathrm{FM}_{2}$ under salt stress conditions, whereas the corresponding increase in the roots was $33.68 \%$ and $81.05 \%$, respectively. With regard to $C$ content, under CK, both the $\mathrm{FM}_{1}$ and $\mathrm{FM}_{2}$ groups showed no obvious difference, whereas the DT group presented significant increase after inoculation. Furthermore, the DT group presented no difference in the N and P uptake under CK and salt stress conditions.

Salt stress had a considerable effect on the $\mathrm{K}^{+}$and $\mathrm{Na}^{+}$contents in the leaves and roots of Z. serrata seedlings, with AMF groups showing a significant difference in the $\mathrm{K}^{+}, \mathrm{Ca}^{2+}, \mathrm{Mg}^{2+}$, and $\mathrm{Na}^{+}$contents in the leaves and $\mathrm{Na}^{+}$content in the roots. Among the three AMF groups, the DT group presented no difference in the $\mathrm{K}^{+}, \mathrm{Ca}^{2+}, \mathrm{Mg}^{2+}$, and $\mathrm{Na}^{+}$contents in the leaves and roots under $\mathrm{CK}$ and salt stress conditions. In contrast, the $\mathrm{FM}_{1}$ and $\mathrm{FM}_{2}$ groups exhibited significant variation in the $\mathrm{K}^{+}, \mathrm{Ca}^{2+}$, $\mathrm{Mg}^{2+}$, and $\mathrm{Na}^{+}$contents under salt stress conditions. In particular, under salt stress conditions, the $\mathrm{K}^{+}$ content in the leaves of the $\mathrm{FM}_{1}$ and $\mathrm{FM}_{2}$ groups increased by $25.05 \%(p<0.05)$ and $31.67 \%(p<0.05)$ after inoculation, while the corresponding increase in the roots were $59.47 \%(p<0.05)$ and $47.84 \%$, respectively. Moreover, the $\mathrm{Ca}^{2+}, \mathrm{Mg}^{2+}$, and $\mathrm{Na}^{+}$contents in the leaves of the $\mathrm{FM}_{1}$ and $\mathrm{FM}_{2}$ groups under salt stress conditions were higher than those in the roots. The $\mathrm{Ca}^{2+}$ content in the leaves of the $\mathrm{FM}_{1}$ and $\mathrm{FM}_{2}$ groups under salt stress conditions increased by $13.66 \%$ and $28.09 \%(p<0.05)$ after inoculation, while the $\mathrm{Mg}^{2+}$ content increased by $35.05 \%(p<0.05)$ and $49.48 \%(p<0.05)$, respectively. On the contrary, the $\mathrm{Na}^{+}$content in the leaves of the $\mathrm{FM}_{1}$ and $\mathrm{FM}_{2}$ groups under salt stress conditions decreased by $20.91 \%$ and $11.06 \%$, while that in the roots decreased by $17.57 \%$ and $11.76 \%$, respectively. 
Table 2. Effects of salt and AMF inoculation on leaf and root nutrient contents.

\begin{tabular}{|c|c|c|c|c|c|c|c|c|}
\hline Salt Status & AM Treatments & C (mg/g) & N (mg/g) & $P(\mathrm{mg} / \mathrm{g})$ & K (mg/g) & $\mathrm{Ca}(\mathrm{mg} / \mathrm{g})$ & $\mathrm{Mg}(\mathrm{mg} / \mathrm{g})$ & $\mathrm{Na}(\mathrm{mg} / \mathrm{g})$ \\
\hline \multicolumn{9}{|c|}{ Leaf } \\
\hline \multirow{4}{*}{ CK } & NM & $435.1 \pm 12.1 \mathrm{bc}$ & $23.6 \pm 2.9 \mathrm{ab}$ & $1.2 \pm 0.2 \mathrm{a}$ & $12.9 \pm 0.4 \mathrm{~cd}$ & $22.3 \pm 1.6 \mathrm{bc}$ & $2.4 \pm 0.3 \mathrm{abc}$ & $1.4 \pm 0.0 \mathrm{~d}$ \\
\hline & $\mathrm{FM}_{1}$ & $448.3 \pm 3.1 \mathrm{ab}$ & $24.1 \pm 1.8 \mathrm{ab}$ & $1.1 \pm 0.1 \mathrm{ab}$ & $11.2 \pm 0.7 \mathrm{~d}$ & $21.5 \pm 1.6 \mathrm{bc}$ & $2.3 \pm 0.1 \mathrm{bc}$ & $1.0 \pm 0.1 \mathrm{~d}$ \\
\hline & $\mathrm{FM}_{2}$ & $443.6 \pm 12.5 \mathrm{abc}$ & $24.5 \pm 2.1 \mathrm{a}$ & $1.3 \pm 0.2 \mathrm{a}$ & $12.5 \pm 0.5 \mathrm{~d}$ & $21.9 \pm 1.5 \mathrm{bc}$ & $2.7 \pm 0.4 \mathrm{ab}$ & $1.1 \pm 0.1 \mathrm{~d}$ \\
\hline & DT & $457.3 \pm 8.3 \mathrm{a}$ & $22.7 \pm 1.3 \mathrm{abc}$ & $1.2 \pm 0.1 \mathrm{a}$ & $11.6 \pm 0.6 \mathrm{~d}$ & $18.6 \pm 3.4 \mathrm{c}$ & $2.4 \pm 0.2 \mathrm{bc}$ & $1.0 \pm 0.1 \mathrm{~d}$ \\
\hline \multirow{4}{*}{ Salt } & NM & $431.0 \pm 4.1 \mathrm{c}$ & $20.5 \pm 0.5 b c$ & $0.9 \pm 0.2 \mathrm{bc}$ & $14.65 \pm 1.3 b c$ & $21.0 \pm 08 b c$ & $1.9 \pm 0.2 c$ & $6.6 \pm 0.1 \mathrm{a}$ \\
\hline & $\mathrm{FM}_{1}$ & $432.8 \pm 10.1 \mathrm{bc}$ & $23.4 \pm 2.7 \mathrm{ab}$ & $1.0 \pm 0.2 \mathrm{abc}$ & $18.3 \pm 1.5 \mathrm{a}$ & $24.4 \pm 2.1 \mathrm{ab}$ & $2.6 \pm 0.1 \mathrm{ab}$ & $5.2 \pm 0.4 \mathrm{c}$ \\
\hline & $\mathrm{FM}_{2}$ & $432.0 \pm 1.1 \mathrm{c}$ & $19.7 \pm 2.3 c$ & $0.9 \pm 0.1 \mathrm{bc}$ & $19.3 \pm 2.2 \mathrm{a}$ & $27.0 \pm 4.7 \mathrm{a}$ & $2.9 \pm 0.4 \mathrm{a}$ & $5.9 \pm 0.5 b$ \\
\hline & DT & $431.2 \pm 9.0 \mathrm{c}$ & $19.5 \pm 0.8 \mathrm{c}$ & $0.8 \pm 0.2 c$ & $15.1 \pm 0.2 \mathrm{~b}$ & $20.5 \pm 1.6 \mathrm{bc}$ & $2.2 \pm 0.2 \mathrm{bc}$ & $6.3 \pm 0.4 \mathrm{ab}$ \\
\hline \multicolumn{9}{|l|}{ Significance } \\
\hline Salt & & $* *$ & $* *$ & $* * *$ & $* * *$ & NS & NS & $* * *$ \\
\hline AMF & & NS & NS & NS & $* *$ & * & $* *$ & $* *$ \\
\hline Salt $\times$ AMF & & NS & NS & NS & $* *$ & NS & NS & $*$ \\
\hline \multicolumn{9}{|c|}{ Root } \\
\hline \multirow{5}{*}{ CK } & NM & $406.7 \pm 0.8 b$ & $14.4 \pm 1.0 \mathrm{ab}$ & $1.5 \pm 0.1 \mathrm{bc}$ & $7.1 \pm 2.0 \mathrm{ab}$ & $17.4 \pm 2.7 \mathrm{a}$ & $2.3 \pm 0.3 \mathrm{a}$ & $1.1 \pm 0.4 \mathrm{~d}$ \\
\hline & FM1 & $404.6 \pm 5.4 b$ & $14.6 \pm 1.0 \mathrm{ab}$ & $1.4 \pm 0.3 \mathrm{bcd}$ & $6.7 \pm 0.3 \mathrm{~b}$ & $17.5 \pm 2.8 \mathrm{a}$ & $2.1 \pm 0.4 \mathrm{a}$ & $1.0 \pm 0.2 \mathrm{~d}$ \\
\hline & FM2 & $400.2 \pm 1.3 \mathrm{~b}$ & $14.1 \pm 0.9 \mathrm{ab}$ & $2.1 \pm 0.0 \mathrm{a}$ & $8.5 \pm 0.9 \mathrm{a}$ & $19.9 \pm 2.0 \mathrm{a}$ & $2.5 \pm 0.4 \mathrm{a}$ & $1.3 \pm 0.1 \mathrm{~d}$ \\
\hline & DT & $420.9 \pm 1.2 \mathrm{a}$ & $12.4 \pm 0.2 \mathrm{~b}$ & $1.3 \pm 0.1 \mathrm{bcd}$ & $7.1 \pm 0.9 \mathrm{ab}$ & $18.6 \pm 3.9 \mathrm{a}$ & $2.5 \pm 0.5 \mathrm{a}$ & $1.1 \pm 0.2 \mathrm{~d}$ \\
\hline & NM & $396.6 \pm 4.2 \mathrm{~b}$ & $16.0 \pm 1.5 \mathrm{a}$ & $1.0 \pm 0.1 \mathrm{~cd}$ & $3.0 \pm 0.3 \mathrm{~d}$ & $16.6 \pm 1.8 \mathrm{a}$ & $1.9 \pm 0.2 \mathrm{a}$ & $7.6 \pm 0.3 \mathrm{a}$ \\
\hline \multirow{3}{*}{ Salt } & FM1 & $405.8 \pm 9.7 \mathrm{~b}$ & $16.0 \pm 0.6 \mathrm{a}$ & $1.3 \pm 0.4 \mathrm{bcd}$ & $4.8 \pm 0.2 \mathrm{c}$ & $16.3 \pm 1.3 \mathrm{a}$ & $2.1 \pm 0.3 \mathrm{a}$ & $6.2 \pm 0.3 c$ \\
\hline & FM2 & $395.8 \pm 15.0 \mathrm{~b}$ & $16.2 \pm 0.8 \mathrm{a}$ & $1.7 \pm 0.4 \mathrm{ab}$ & $4.5 \pm 0.8 \mathrm{~cd}$ & $18.3 \pm 0.5 \mathrm{a}$ & $2.1 \pm 0.2 \mathrm{a}$ & $6.7 \pm 0.2 \mathrm{~b}$ \\
\hline & DT & $395.7 \pm 10.6 b$ & $14.9 \pm 3.6 \mathrm{ab}$ & $0.8 \pm 0.2 \mathrm{~d}$ & $4.1 \pm 0.1 \mathrm{~cd}$ & $15.6 \pm 1.8 \mathrm{a}$ & $1.9 \pm 0.1 \mathrm{a}$ & $7.6 \pm 0.3 \mathrm{a}$ \\
\hline \multicolumn{9}{|l|}{ Significance } \\
\hline Salt & & $* *$ & $* *$ & $* *$ & $* * *$ & NS & * & $* * *$ \\
\hline AMF & & NS & NS & $* *$ & NS & NS & NS & $* * *$ \\
\hline Salt $\times$ AMF & & NS & NS & NS & NS & NS & NS & $* *$ \\
\hline
\end{tabular}

Notes: CK represents the control without salt and AMF. NM represents the control treatments without AMF, FM1 represents treatments inoculated with the AMF Funneliformis mosseae 1,

FM2 represents treatments inoculated with the AMF Funneliformis mosseae 2, DT represents treatments inoculated with the AMF Diversispora tortuosum. Different lowercase letters indicate significant differences between the three AMF under control and salt stress at the 0.05 significance level; NS not significant, ${ }^{*} p<0.05, * * p<0.01,{ }^{* * *} p<0.001$. 


\section{Discussion}

The impact of excessive salinity on forest trees is widespread and costly all over the world [22]. High salt concentrations always damage trees, even causing death, and have severely affected the construction of coastal wetland forests in Southeastern USA and coastal afforestation projects in China. Some strategies have been developed to improve the salt tolerance of trees, including breeding, genetic engineering, and microbiological techniques [23], among which the application of AMF is a relatively cost-effective method. Although many studies have demonstrated that the inoculation of AMF can alleviate salt stress in plants [13,24-31], they mainly focused on agriculture crops. It has been reported that damage caused by salt stress in some tree seedlings, such as citrus (Citrus reticulata Blanco.) [26], black locust (Robinia pseudoacacia Linn.) [32], and oleaster (Elaeagnus angustifolia Linn.) [33], were alleviated after AMF inoculation; however, research on the effect of AMF on salt tolerance of tree seedlings remains limited.

The colonization capacity of AMF depends on AMF species and plant species [12]. In the present study, the three AMF species presented high colonization percentages with Z. serrata seedlings, although the colonization percentages differed among them, which are consistent with the results of previous studies on maize [12]. Moreover, salinity has been reported to cause a reduction in AMF colonization percentages $[12,26,32]$, similar to the findings of the present study, suggesting that salinity might suppress AMF hyphal growth, sporulation, and spore germination [34,35]. Previous works have demonstrated that AMF-inoculated plants exhibit better growth than non-inoculated plants [36,37]. For instance, mycorrhizal black locust seedlings were found to show higher shoot and root dry weight under different salt levels [32]. Similarly, an increase in stem, leaves, and total dry weight was observed in mycorrhizal bamboo reed (Arundo donax Linn.) plant when compared with those in non-mycorrhizal A. donax under salt stress [28]. In the present study, the Z. serrata seedlings inoculated with F. mosseae 1, F. mosseae 2 and D. tortuosum strains (especially F. mosseae 1 and F. mosseae 2 strains) presented higher growth of seedling height, growth of seedling diameter, leaf area, and root, stem, and leaves dry weight, when compared with non-mycorrhizal seedlings under both normal and salt stress conditions. These results are in agreement with those reported in a previous study on wheat inoculated with different AMF strains in saline soil [25], indicating that F. mosseae 1 and F. mosseae 2 strains have higher symbiotic efficiency on Z. serrata seedlings than Glomus tortuosum. The positive impact of AMF symbiosis on plants growth and development under salt stress could partly be attributed to the enhancement of nutrients and water acquisition by external mycorrhizal hyphae $[25,38]$. However, high salt stress may restrain the development of mycorrhizal hyphae [39]. In the present study, the growth of $Z$. serrata seedlings inoculated with $D$. tortuosum was not better than that of non-mycorrhizal seedlings under salt stress.

It is well known that soil salinity inhibits the photosynthetic ability of plants, resulting in decrease in plant growth and biomass accumulation [40]. Salinity reduces the photosynthetic capability of plants mainly by damaging the photosynthetic apparatus and diminishing the photosynthetic pigments content [41]. Previous evidence has demonstrated that AMF can improve the photosynthetic ability of plants mainly by enhancing the gas exchange capacity, photosynthetic pigments content, and photochemistry and non-photochemistry of PSII and the water status of leaves [3,42]. In the present study, the net photosynthetic rates of seedlings inoculated with F. mosseae 1 and F. mosseae 2 strains were significantly increased under salt stress conditions, which could be attributed to the ability of the AMF strains to enhance the photosynthetic pigment content, similar to that reported in previous studies $[43,44]$. The increased photosynthetic pigment content, which allows seedlings to obtain more energy from light [44], might be related to the increase in nutrient uptake caused by AMF [45], as indicated by the higher P and Mg contents in the seedlings inoculated with AMF. The net photosynthetic rates of $Z$. serrata seedlings inoculated with $D$. tortuosum strain were significantly higher under $C K$, but showed no difference under salt stress conditions. Additionally, the increased relative water content and stomatal conductance in the leaves indicated that $D$. tortuosum strain can enhance the photosynthetic ability of $Z$. serrata by elevating the gas exchange capability and water status under 
$C K$, as reported in a previous study [46]. Moreover, D. tortuosum inoculation led to enhanced C fixation in Z. serrata leaves, resulting in higher total C content, which ultimately caused an increase in the growth and biomass of the seedlings [47]. However, the influence of D. tortuosum on enhancing the photosynthetic ability of Z. serrata seedlings disappeared under salt stress, which may be due to the adverse effect of salt on $D$. tortuosum. Furthermore, although photosynthesis and photosynthetic pigments of Z. serrata seedlings were affected by AMF, the leaf photochemical properties were not significantly influenced by the three AMF strains, similar to what may be observed in $A$. donax under salt stress [28].

Soil salinity is known to significantly inhibit the absorption of mineral nutrients by plants, and AMF have been proven to exhibit a positive impact on mineral nutrients absorption and selection by plants through their numerous extraradical mycorrhizal hyphae spread in the soil $[8,48,49]$. However, the ability to uptake nutrients by AMF is found to vary with the fungal and plant species as well as soil salt concentration [28,48]. For instance, F. mosseae had been reported to significantly increase the $\mathrm{P}$, $\mathrm{N}, \mathrm{K}^{+}, \mathrm{Ca}^{2+}$, and $\mathrm{Mg}^{2+}$ concentrations in the shoots of wheat (Triticum aestivium Linn.) plants in saline soil, whereas Gigaspora gergaria had no obvious effects on the nutrient uptake of wheat. In the present study, F. mosseae 1 and F. mosseae 2 strains had obvious positive effects on nutrient uptake of Z. serrata seedlings under salt stress conditions, when compared with non-mycorrhizal seedlings, whereas $D$. tortuosum strain had no effects on the nutrient uptake of Z. serrata seedlings.

In general, a high content of $\mathrm{Na}$ salts in the soil can affect nutrient availability, especially nutrient uptake, transport, or distribution within plants [50]. $\mathrm{N}$ is an essential macronutrient to plants; it participates in the synthesis of proteins and serves as a constituent of plant cell components. Salinity can interfere with $\mathrm{N}$ acquisition, utilization, and metabolism of plants, leading to a decrease in plant growth [50]. A previous study demonstrated that mycorrhizal vegetable hummingbird (Sesbania grandiflora (Linn.) Pers) and sesbania (Sesbania aegyptiaca (Linn.) Pers) had higher N accumulation in shoots compared with non-mycorrhizal control plants [49]. However, the results of the present study showed no obvious difference between mycorrhizal and non-mycorrhizal seedlings. P plays a key role in the formation of an integral component of plant cell structure compounds [51]. As an essential macronutrient, the reduction of $\mathrm{P}$ content in plants caused by salt stress can result in reduced and stunted growth [52]. Many reports have indicated that AMF can enhance the absorption of $\mathrm{P}$ and increase its concentration in plants under salt stress conditions. In the present study, an obvious increase in the concentration of $\mathrm{P}$ was noted in the leaves and roots of $Z$. serrata seedlings inoculated with F. mosseae 1 and F. mosseae 2 strains under salt stress, when compared with that in non-mycorrhizal seedlings. This increase in P content might be attributed to the extensive hyphal network of the AMF, which cover more soil volume and increase the absorption surface area of roots [53], or the P transport capacity of AMF was less influenced by salt stress than plants. Improved $P$ content in mycorrhizal plants under salt stress conditions may contribute to the maintenance of vacuolar membrane integrity and facilitate compartmentalization of $\mathrm{Na}^{+}$within the vacuoles and selective ions uptake, thereby reducing the adverse impacts of salinity on growth and metabolism, and ultimately improving plant growth $[54,55] . \mathrm{K}^{+}$plays a key role in plant metabolism, including stomatal movement, protein synthesis, and enzymes activation, and excess $\mathrm{Na}^{+}$in soil can cause plants to take up more $\mathrm{Na}^{+}$and decrease the absorption of $\mathrm{K}^{+}$[56]. However, uptake of $\mathrm{K}^{+}$has been reported to increase in plants under salt stress after AMF inoculation [8]. In the present study, a marked increase in $\mathrm{K}^{+}$and decrease in $\mathrm{Na}^{+}$content in Z. serrata seedlings inoculated with F. mosseaee 1 and F. mosseae 2 strains under salt stress was observed. A higher $\mathrm{K}^{+}: \mathrm{Na}^{+}$ratio in leaves and roots of mycorrhizal seedlings prevented disruption of cellular enzymatic processes and inhibition of protein synthesis, which might be an important mechanism of F. mosseae to alleviate salt stress in Z. serrata seedlings. Furthermore, mycorrhization also contributed to overcoming $\mathrm{Na}^{+}$-induced $\mathrm{Ca}^{2+}$ and $\mathrm{Mg}^{2+}$ deficiencies. A significant increase in $\mathrm{Mg}^{2+}$ content in the leaves and roots of $Z$. serrata seedlings inoculated with F. mosseae 1 and F. mosseae 2 strains under salt stress was observed, similar to that reported for citrus 
seedlings inoculated with AMF [26], which might be attributed with an increase in photosynthetic pigments content and improvements in photosynthetic ability [57].

\section{Conclusions}

This study demonstrated that salt stress significantly induced inhibition of growth, photosynthesis, and nutrient uptake of $Z$. serrata seedlings. Although all the three examined AMF strains had positive effects, to some extent, on the growth and photosynthesis of $Z$. serrata seedlings under normal condition, only F. mosseae 1 and F. mosseae 2 strains alleviated the inhibition of growth, photosynthesis, and nutrient uptake of the seedlings induced by salt stress. However, the effects of $F$. mosseae 1 and F. mosseae 2 strains on Z. serrata seedlings presented no significant difference. The two AMF strains alleviated salt stress of the seedlings predominantly by reducing $\mathrm{Na}^{+}$uptake, increasing $\mathrm{P}, \mathrm{K}^{+}$, and $\mathrm{Mg}^{2+}$ uptake, and by enhancing the photosynthetic pigments content and stomatal conductance of leaves, ultimately resulting in an increase in photosynthesis and biomass. These findings indicated that AMF have promising applications in the afforestation and vegetation rehabilitation of coastal areas; nevertheless, further studies are needed to select suitable AMF species for appropriate trees.

Author Contributions: J.Z. and J.W. conceived the experiments. J.W., Z.F., L.Z., Q.R., X.C. and J.M. conducted the experiments. J.W. and J.L. interpreted data. J.W. wrote the manuscript. J.Y. revised the manuscript. All authors read and approved the final manuscript.

Funding: This work was financially supported by the Agricultural Science and Technology Independent Innovation Fund of Jiangsu province of China (Grant No. CX (17) 004), the National Natural Science Foundation of China (Grant No. 31470709), the National Special Fund for Forestry Scientific Research in the Public Interest (Grant No. 201504406), the Major Fund for Natural Science of Jiangsu Higher Education Institutions (Grant No. 15KJA220004), the Forestry Extension Technical Fund (Grant No. [2015]17), the Priority Academic Program Development of Jiangsu Higher Education Institutions (PAPD), and the Doctorate Fellowship Foundation of Nanjing Forestry University (2169125).

Acknowledgments: We thank International Science Editing (http:/ / www.internationalscienceediting.com) for editing manuscript.

Conflicts of Interest: The authors declare no conflict of interest.

\section{References}

1. Horikawa, K. Coast. Dunes: Form and Process; Nordstrom, K.F., Psuty, N., Carter, B., Eds.; Wiley: Chichester, UK, 1990; ISBN 0-471-91842-3. [CrossRef]

2. Rodrigues, R.S.; Mascarenhas, A.; Jagtap, T.G. An evaluation of flora from coastal sand dunes of India: Rationale for conservation and management. Ocean Coast. Manag. 2011, 54, 181-188. [CrossRef]

3. Ruizlozano, J.M.; Porcel, R.; Azcón, C.; Aroca, R. Regulation by arbuscular mycorrhizae of the integrated physiological response to salinity in plants: New challenges in physiological and molecular studies. J. Exp. Bot. 2012, 63, 4033-4044. [CrossRef]

4. Munns, R.; James, R.A.; Lauchi, A. Approaches to increasing the salt tolerance of wheat and other cereals. J. Exp. Bot. 2006, 57, 1025-1043. [CrossRef] [PubMed]

5. Kumar, A.; Dames, J.F.; Gupta, A.; Sharma, S.; Gilbert, J.A.; Ahmad, P. Current developments in arbuscular mycorrhizal fungi research and its role in salinity stress alleviation: A biotechnological perspective. Crit. Rev. Biotechnol. 2015, 35, 461-474. [CrossRef] [PubMed]

6. LóPez-Ráez, J.A. How drought and salinity affect arbuscular mycorrhizal symbiosis and strigolactone biosynthesis? Planta 2016, 243, 1375-1385. [CrossRef]

7. Spatafora, J.W.; Chang, Y.; Benny, G.L.; Lazarus, K.; Smith, M.E.; Berbee, M.L.; Bomito, G.; Corradi, N.; Grigoriev, I.; Gryganskyi, A. A phylum-level phylogenetic classification of zygomycete fungi based on genome-scale data. Mycologia 2016, 108, 1028-1046. [CrossRef] [PubMed]

8. Giri, B.; Kapoor, R.; Mukerji, K.G. Improved tolerance of Acacia nilotica to salt stress by arbuscular mycorrhiza, Glomus fasciculatum may be partly related to elevated $\mathrm{K} / \mathrm{Na}$ ratios in root and shoot tissues. Microb. Ecol. 2007, 54, 753-760. [CrossRef] 
9. Frosi, G.; Barros, V.A.; Oliveira, M.T.; Santos, M.; Ramos, D.G.; Maia, L.C.; Santos, M.G. Arbuscular mycorrhizal fungi and foliar phosphorus inorganic supply alleviate salt stress effects in physiological attributes, but only arbuscular mycorrhizal fungi increase biomass in woody species of a semiarid environment. Tree Physiol. 2017, 38, 25-36. [CrossRef] [PubMed]

10. Leifheit, E.F.; Veresoglou, S.D.; Lehmann, A.; Kathryn Morris, E.; Rillig, M.C. Multiple factors influence the role of arbuscular mycorrhizal fungi in soil aggregation-A meta-analysis. Plant Soil 2014, 374, 523-537. [CrossRef]

11. Chandrasekaran, M.; Boughattas, S.; Hu, S.J.; Oh, S.H.; Sa, T.M. A meta-analysis of arbuscular mycorrhizal effects on plants grown under salt stress. Mycorrhiza 2014, 24, 611-625. [CrossRef] [PubMed]

12. Estrada, B.; Aroca, R.; Maathuis, F.J.; Barea, J.M.; Ruizlozano, J.M. Arbuscular mycorrhizal fungi native from a Mediterranean saline area enhance maize tolerance to salinity through improved ion homeostasis. Plant Cell Environ. 2013, 36, 1771-1782. [CrossRef] [PubMed]

13. Porcel, R.; Redondogómez, S.; Mateosnaranjo, E.; Aroca, R.; Garcia, R.; Ruiziozano, J.M. Arbuscular mycorrhizal symbiosis ameliorates the optimum quantum yield of photosystem II and reduces non-photochemical quenching in rice plants subjected to salt stress. J. Plant Physiol. 2015, 185, 75-83. [CrossRef] [PubMed]

14. Aroca, R.; Bago, A.; Sutka, M.; Paz, J.A.; Cano, C.; Amodeo, G.; Ruiz-Lozano, J.M. Expression analysis of the first arbuscular mycorrhizal fungi aquaporin described reveals concerted gene expression between salt-stressed and nonstressed mycelium. Mol. Plant Microbe Interact. 2009, 22, 1169-1178. [CrossRef]

15. Dou, Q.Q.; Jiao, X.J.; Zhang, M.; Kai-Yue, H.H.; Huang, L.B. Physiological response of Zelkova schneideriana seedlings in the soil under $\mathrm{NaCl}$ stress. Acta Bot. Boreali-Occident. Sin. 2009, 22, 2063-2069.

16. Phillips, J.M.; Hayman, D.S. Improved procedures for clearing roots and staining parasitic and vesicular-arbuscular mycorrhizal fungi for rapid assessment of infection. Trans. Br. Mycol. Soc. 1970, 55, 158-161. [CrossRef]

17. Liu, X.; Fu, Z.Y.; Zhang, B.; Zhai, L.; Meng, M.J.; Lin, J.; Zhuang, J.Y.; Wang, G.G.; Zhang, J.C. Effects of sulfuric, nitric, and mixed acid rain on Chinese fir sapling growth in Southern China. Ecotoxicol. Environ. Saf. 2018, 160, 154-161. [CrossRef] [PubMed]

18. Lichtenthaler, H.K. Chlorophylls and carotenoids: Pigments of photosynthetic biomembranes. Methods Enzymol. 1987, 148, 350-382.

19. Yue, J.M.; Fu, Z.Y.; Zhang, L.; Zhang, Z.H.; Zhang, J.C. The positive effect of different 24-epiBL pretreatments on salinity tolerance in Robinia pseudoacacia L. seedlings. Forests 2019, 10, 4. [CrossRef]

20. Yue, J.M.; You, Y.Y.; Zhang, L.; Fu, Z.Y.; Wang, J.P.; Zhang, J.C.; Robert, D.G. Exogenous 24-epibrassinolide alleviates effects of salt stress on chloroplasts and photosynthesis in Robinia pseudoacacia L. seedlings. J. Plant Growth Regul. 2018, 1-14. [CrossRef]

21. Allen, M. Mycorrhizae and rehabilitation of disturbed arid soils: Processes and practices. Arid Soil Res. Rehabil. 1989, 3, 229-241. [CrossRef]

22. Paludan-Müller, G.; Saxe, H.; Pedersen, L.B.; Randrup, T.B. Differences in salt sensitivity of four deciduous tree species to soil or airborne salt. Physiol. Plant. 2010, 114, 223-230. [CrossRef]

23. Allen, J.A.; Chambers, J.L.; Stine, M. Prospects for increasing the salt tolerance of forest trees: A review. Tree Physiol. 1994, 14, 843-853. [CrossRef] [PubMed]

24. Estrada, B.; Barea, M.J.; Aroca, R.; Ruiz-Lozano, J.M. A native Glomus intraradices strain from a Mediterranean saline area exhibits salt tolerance and enhanced symbiotic efficiency with maize plants under salt stress conditions. Plant Soil 2013, 366, 333-349. [CrossRef]

25. Abdel-Fattah, G.M. Arbuscular mycorrhizal fungal application to improve growth and tolerance of wheat (Triticum aestivum L.) plants grown in saline soil. Acta Physiol. Plant. 2012, 34, 267-277. [CrossRef]

26. Navarro, J.M.; Olaya, P.R.T.; Asunciã, N.M. Alleviation of salt stress in citrus seedlings inoculated with arbuscular mycorrhizal fungi depends on the rootstock salt tolerance. J. Plant Physiol. 2014, 171, 76-85. [CrossRef] [PubMed]

27. Hajiboland, R.; Aliasgharzadeh, N.; Laiegh, S.F.; Poschenrieder, C. Colonization with arbuscular mycorrhizal fungi improves salinity tolerance of tomato (Solanum lycopersicum L.) plants. Plant Soil 2010, 331, 313-327. [CrossRef] 
28. Pollastri, S.; Savvides, A.; Pesando, M.; Lumini, E.; Volpe, M.G.; Ozudogru, E.E.; Faccio, A.; Cunzo, F.F.; Michelozzi, M.; Lambardi, M.; et al. Impact of two arbuscular mycorrhizal fungi on Arundo donax L. response to salt stress. Planta 2018, 247, 573-585. [CrossRef]

29. Liu, S.L.; Guo, X.L.; Feng, G.; Maimaitiaili, B.; Fan, J.L.; He, X.H. Indigenous arbuscular mycorrhizal fungi can alleviate salt stress and promote growth of cotton and maize in saline fields. Plant Soil 2016, 398, 195-206. [CrossRef]

30. Qu, L.Q.; Huang, Y.Y.; Zhu, C.M.; Zeng, H.Q.; Shen, C.J.; Liu, C.; Zhao, Y.; Pi, E.X. Rhizobia-inoculation enhances the soybean's tolerance to salt stress. Plant Soil 2016, 400, 209-222. [CrossRef]

31. Zhang, T.; Hu, Y.; Zhang, K.; Tian, C.Y.; Guo, J.X. Arbuscular mycorrhizal fungi improve plant growth of Ricinus communis by altering photosynthetic properties and increasing pigments under drought and salt stress. Ind. Crop. Prod. 2018, 117, 13-19. [CrossRef]

32. Chen, J.; Zhang, H.; Zhang, X.; Tang, M. Arbuscular mycorrhizal symbiosis alleviates salt stress in Black locust through improved photosynthesis, water status, and $\mathrm{K}^{+} / \mathrm{Na}^{+}$homeostasis. Front. Plant Sci. 2017, 8, 1739. [CrossRef] [PubMed]

33. Chang, W.; Sui, X.; Fan, X.X.; Jia, T.T.; Song, F.Q. Arbuscular mycorrhizal symbiosis modulates antioxidant response and ion distribution in salt-stressed Elaeagnus angustifolia Seedlings. Front. Microbiol. 2018, 9, 652. [CrossRef] [PubMed]

34. Juniper, S.; Abbott, L.K. Soil salinity delays germination and limits growth of hyphae from propagules of arbuscular mycorrhizal fungi. Mycorrhiza 2006, 16, 371-379. [CrossRef] [PubMed]

35. Jahromi, F.; Aroca, R.; Porcel, R.; Ruiz-Lozano, J.M. Influence of salinity on the in vitro development of Glomus intraradices and on the in vivo physiological and molecular responses of mycorrhizal lettuce plants. Microb. Ecol. 2008, 55, 45-53. [CrossRef] [PubMed]

36. Zhang, Z.F.; Zhang, J.C.; Huang, Y.Q. Effects of arbuscular mycorrhizal fungi on the drought tolerance of Cyclobalanopsis glauca seedlings under greenhouse conditions. New For. 2014, 45, 545-556. [CrossRef]

37. Urgiles, N.; Strauß, A.; Loján, P.; Schüßler, A. Cultured arbuscular mycorrhizal fungi and native soil inocula improve seedling development of two pioneer trees in the Andean region. New For. 2014, 45, 859-874. [CrossRef]

38. Azcón, R.; El-Atrash, F. Influence of arbuscular mycorrhizae and phosphorus fertilization on growth, nodulation and $\mathrm{N}_{2}$ fixation $\left({ }^{15} \mathrm{~N}\right)$ in Medicago sativa at four salinity levels. Biol. Fertil. Soils 1997, 24, 81-86. [CrossRef]

39. Miransari, M.; Bahrami, H.A.; Rejali, F.; Malakouti, M.J. Using arbuscular mycorrhiza to alleviate the stress of soil compaction on wheat (Triticum aestivum L.) growth. Soil Biol. Biochem. 2008, 40, 1197-1206. [CrossRef]

40. Pitman, M.G.; Läuchli, A. Global Impact of salinity and agricultural ecosystems. In Salinity: Environment-Plants-Molecules; Springer: Dordrecht, The Netherlands, 2002; pp. 3-20.

41. Akram, M.S.; Ashraf, M. Exogenous application of potassium dihydrogen phosphate can alleviate the adverse effects of salt stress on sunflower. J. Plant Nutr. 2011, 34, 1041-1057. [CrossRef]

42. Zuccarini, P.; Okurowska, P. Effects of mycorrhizal colonization and fertilization on growth and photosynthesis of sweet basil under salt stress. J. Plant Nutr. 2008, 31, 497-513. [CrossRef]

43. Talaat, N.B.; Shawky, B.T. Protective effects of arbuscular mycorrhizal fungi on wheat (Triticum aestivum L.) plants exposed to salinity. Environ. Exp. Bot. 2014, 98, 20-31. [CrossRef]

44. Zai, X.M.; Zhu, S.N.; Qin, P.; Wang, X.Y.; Che, L.; Luo, F.X. Effect of Glomus mosseae on chlorophyll content, chlorophyll fluorescence parameters, and chloroplast ultrastructure of beach plum (Prunus maritima) under $\mathrm{NaCl}$ stress. Photosynthetica 2012, 50, 323-328. [CrossRef]

45. Zhu, X.C.; Song, F.B.; Xu, H.W. Arbuscular mycorrhizae improves low temperature stress in maize via alterations in host water status and photosynthesis. Plant Soil 2010, 331, 129-137. [CrossRef]

46. Aroca, R.; Ruiz-Lozano, J.M.; Zamarreño, A.M.; Paz, J.A.; Garcia-Mina, J.M.; Pozo, M.J.; López-Ráez, J.A. Arbuscular mycorrhizal symbiosis influences strigolactone production under salinity and alleviates salt stress in lettuce plants. J. Plant Physiol. 2013, 170, 47-55. [CrossRef]

47. Kiers, E.T.; Duhamei, M.; Beesetty, Y.; Mensah, J.A.; Franken, O.; Verbruggen, E.; Fellbaum, C.R.; Kowalchuk, G.A.; Hart, M.M.; Bago, A.; et al. Reciprocal rewards stabilize cooperation in the mycorrhizal symbiosis. Science 2011, 333, 880-882. [CrossRef]

48. Tian, C.Y.; Feng, G.; Li, X.L.; Zhang, F.S. Different effects of arbuscular mycorrhizal fungal isolates from saline or non-saline soil on salinity tolerance of plants. Appl. Soil Ecol. 2004, 26, 143-148. [CrossRef] 
49. Giri, B.; Mukerji, K.G. Mycorrhizal inoculant alleviates salt stress in Sesbania aegyptiaca and Sesbania grandiflora under field conditions: Evidence for reduced sodium and improved magnesium uptake. Mycorrhiza 2004, 14, 307-312. [CrossRef]

50. Munns, R.; Tester, M. Mechanisms of salinity tolerance. Annu. Rev. Plant Biol. 2008, 59, 651-681. [CrossRef]

51. Taiz, L.; Zeiger, E. Plant physiology. Q. Rev. Biol. 2006, 167, 161-168.

52. Giri, B.; Kapoor, R.; Mukerji, K.G. Influence of arbuscular mycorrhizal fungi and salinity on growth, biomass, and mineral nutrition of Acacia auriculiformis. Biol. Fertil. Soils 2003, 38, 170-175. [CrossRef]

53. Ruiz-Lozano, J.M.; Azcón, R. Symbiotic efficiency and infectivity of an autochthonous arbuscular mycorrhizal Glomus sp. from saline soils and Glomus deserticola under salinity. Mycorrhiza 2000, 10, 137-143. [CrossRef]

54. Cantrell, I.C.; Linderman, R.G. Preinoculation of lettuce and onion with VA mycorrhizal fungi reduces deleterious effects of soil salinity. Plant Soil 2001, 233, 269-281. [CrossRef]

55. Rinaldelli, E.; Mancuso, S. Response of young mycorrhizal and non-mycorrhizal plants of olive tree (Olea europaea L.) to saline conditions. I. Short-term electrophysiological and long-term vegetative salt effects. Adv. Hortic. Sci. 1996, 10, 126-134.

56. Evelin, H.; Kapoor, R.; Giri, B. Arbuscular mycorrhizal fungi in alleviation of salt stress: A review. Ann. Bot. 2009, 104, 1263-1280. [CrossRef] [PubMed]

57. Khalil, H.A.; Eissa, A.M.; El-Shazly, S.M.; Nasr, A.M.A. Improved growth of salinity-stressed citrus after inoculation with mycorrhizal fungi. Sci. Hortic. 2011, 130, 624-632. [CrossRef]

(C) 2019 by the authors. Licensee MDPI, Basel, Switzerland. This article is an open access article distributed under the terms and conditions of the Creative Commons Attribution (CC BY) license (http://creativecommons.org/licenses/by/4.0/). 